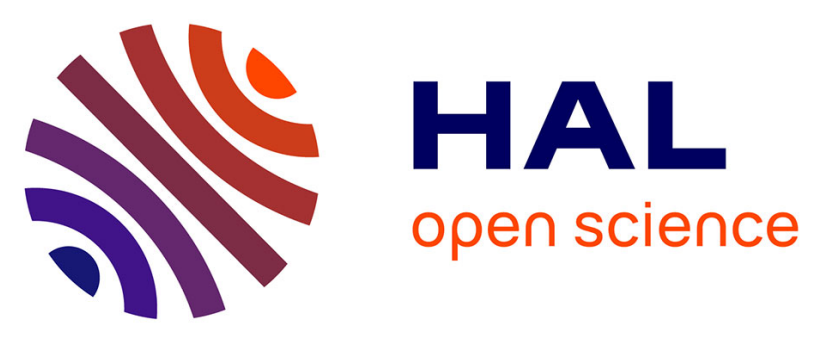

\title{
Single-Electron-Transfer Oxidation of Trifluoroborates and Silicates with Organic Reagents: A Comparative Study
}

Ludwig Chenneberg, Christophe Lévêque, Vincent Corcé, Alexandre Baralle, Jean-Philippe Goddard, Cyril Ollivier, Louis Fensterbank

\section{To cite this version:}

Ludwig Chenneberg, Christophe Lévêque, Vincent Corcé, Alexandre Baralle, Jean-Philippe Goddard, et al.. Single-Electron-Transfer Oxidation of Trifluoroborates and Silicates with Organic Reagents: A Comparative Study. SYNLETT, 2016, 27 (05), pp.731-735. 10.1055/s-0035-1561337 . hal-01301996

\section{HAL Id: hal-01301996 https://hal.sorbonne-universite.fr/hal-01301996}

Submitted on 13 Apr 2016

HAL is a multi-disciplinary open access archive for the deposit and dissemination of scientific research documents, whether they are published or not. The documents may come from teaching and research institutions in France or abroad, or from public or private research centers.
L'archive ouverte pluridisciplinaire HAL, est destinée au dépôt et à la diffusion de documents scientifiques de niveau recherche, publiés ou non, émanant des établissements d'enseignement et de recherche français ou étrangers, des laboratoires publics ou privés. 


\section{Single Electron Transfer Oxidation of Trifluoroborates and Silicates with Organic Reagents: a Comparative Study}

\author{
Ludwig Chenneberg, Christophe Lévêque, \\ Vincent Corcé, Alexandre Baralle, Jean- \\ Philippe Goddard, ${ }^{* b}$ Cyril Ollivier, ${ }^{* a}$ Louis \\ Fensterbank*a \\ ${ }^{a}$ Institut Parisien de Chimie Moléculaire, UMR CNRS 8232, \\ Sorbonne Universités UPMC Univ Paris 06. 4 Place Jussieu, \\ CC 229, F-75252 Paris Cedex 05, France \\ b Laboratoire de Chimie Organique et Bioorganique EA 4566, \\ Université de Haute-Alsace, Ecole Nationale Supérieure de \\ Chimie de Mulhouse. 3 Bis rue Alfred Werner, 68093 \\ Mulhouse Cedex, France \\ * jean-philippe.goddard@uha.fr; cyril.ollivier@upmc.fr;
} louis.fensterbank@upmc.fr

Click here to insert a dedication.

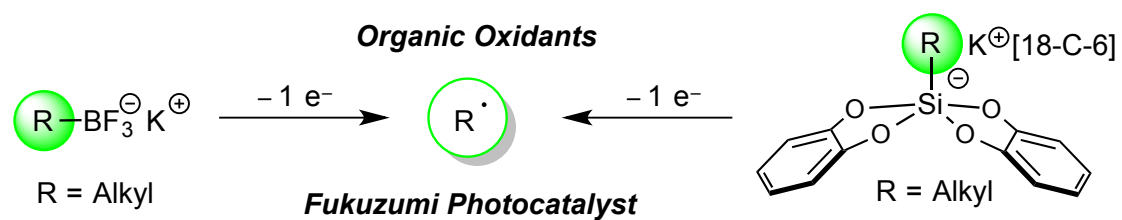

Fukuzumi Photocatalyst
$\mathrm{R}=$ Alkyl

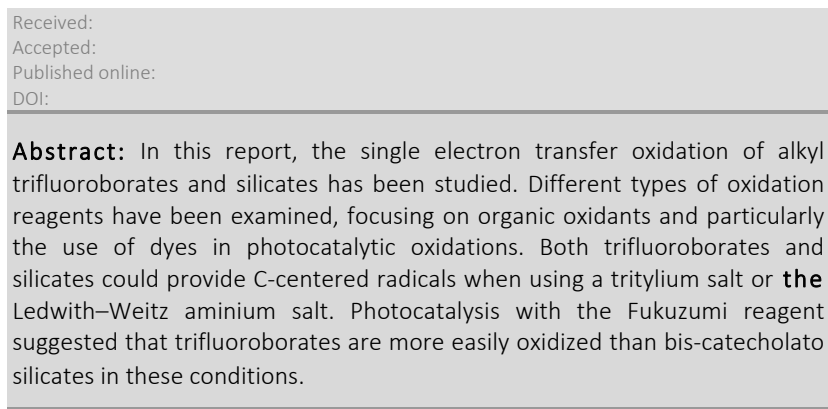

Key words radicals, dyes, photocatalysis, trifluoroborates, silicates, single electron transfer, oxidation

The single electron transfer (SET) oxidation of soft carbanions is a very versatile method to access to $\mathrm{C}$-centered radicals. ${ }^{1}$ Among possible candidates, ate complexes based for instance on boron, trifluoroborates being the most popular reagents, have already shown versatile reactivities for the generation of radicals. ${ }^{2}$ To a lesser extent, hypervalent bis-catecholato silicon species have recently emerged as very promising alternatives to the boron derivatives, avoiding any release of noxious fluorinated byproducts. ${ }^{3}$ Their synthesis is known ${ }^{4}$ yielding bench stable compounds ${ }^{3}$ and their high electron density make them suitable candidates for oxidation. In this letter, we provide new elements on the SET oxidation of alkyl trifluoroborates $\mathbf{1}$ and silicates $\mathbf{3}$, notably focusing on the use of organic oxidants (Scheme 1).

Our own endeavors in this domain started with the copper(II) mediated oxidation of alkyl trifluoroborates 1 (Scheme 1), ${ }^{5}$ a previously known reaction ${ }^{6}$ but not exploited in radical chemistry. In conditions inspired from the related copper(II) oxidation of alkyl pentafluorosilicates $\mathbf{2}$ by Kumada and coworkers, ${ }^{7}$ a series of alkyl (from primary to tertiary ones) trifluoroborates were engaged in oxidative processes. Postfunctionalization of the resulting radical intermediate was achieved by TEMPO spin trapping, allylation and conjugate addition. ${ }^{5}$

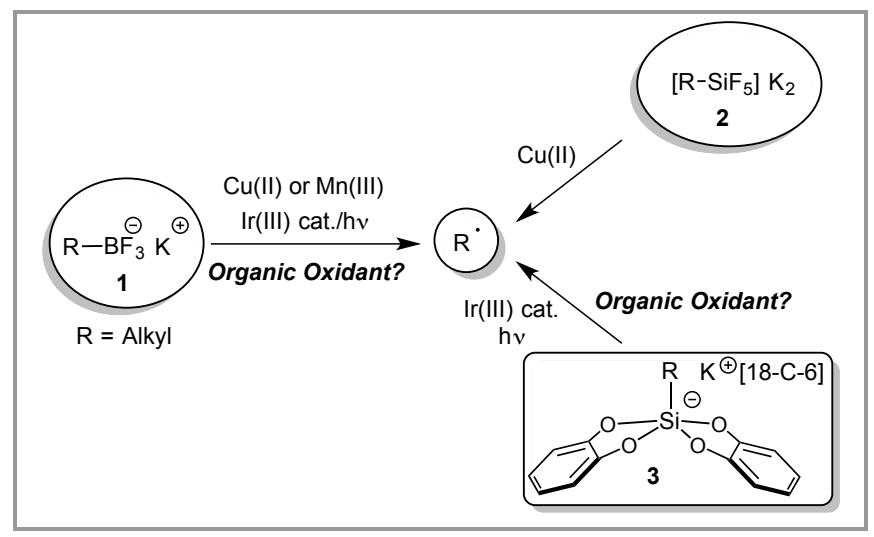

Scheme 1

Following these preliminary reports, we wanted to investigate the use of non-metallic oxidants. We initially showed that the Dess Martin periodinane (DMP) could be efficiently used for the oxidation of trifluoroborates. ${ }^{5}$ Tritylium tetrafluoroborate, an underexplored oxidant, ${ }^{8}$ was also tested with a series of trifluoroborates (Scheme 2). For reasons which need to be elucidated, DMF did not appear as the best solvent for these oxidations. Gratifyingly, good yields of TEMPO adducts 4 were obtained in $\mathrm{Et}_{2} \mathrm{O}$ as solvent with benzyl precursor (4a obtained), but also in secondary (4e and $\mathbf{4 g}$ ) and primary series $\left(\mathbf{4 d}, \mathbf{d}^{\prime}\right) .{ }^{9}$ Only tert-butyl precursor $\mathbf{1 f}$ failed to give a good yield of product (4f, 25\%), presumably for steric reasons. Interestingly, these conditions proved to be compatible with conjugate addition since methyl vinyl ketone (MVK) adduct $\mathbf{5}$ was isolated in satisfactory yield (63\%). 


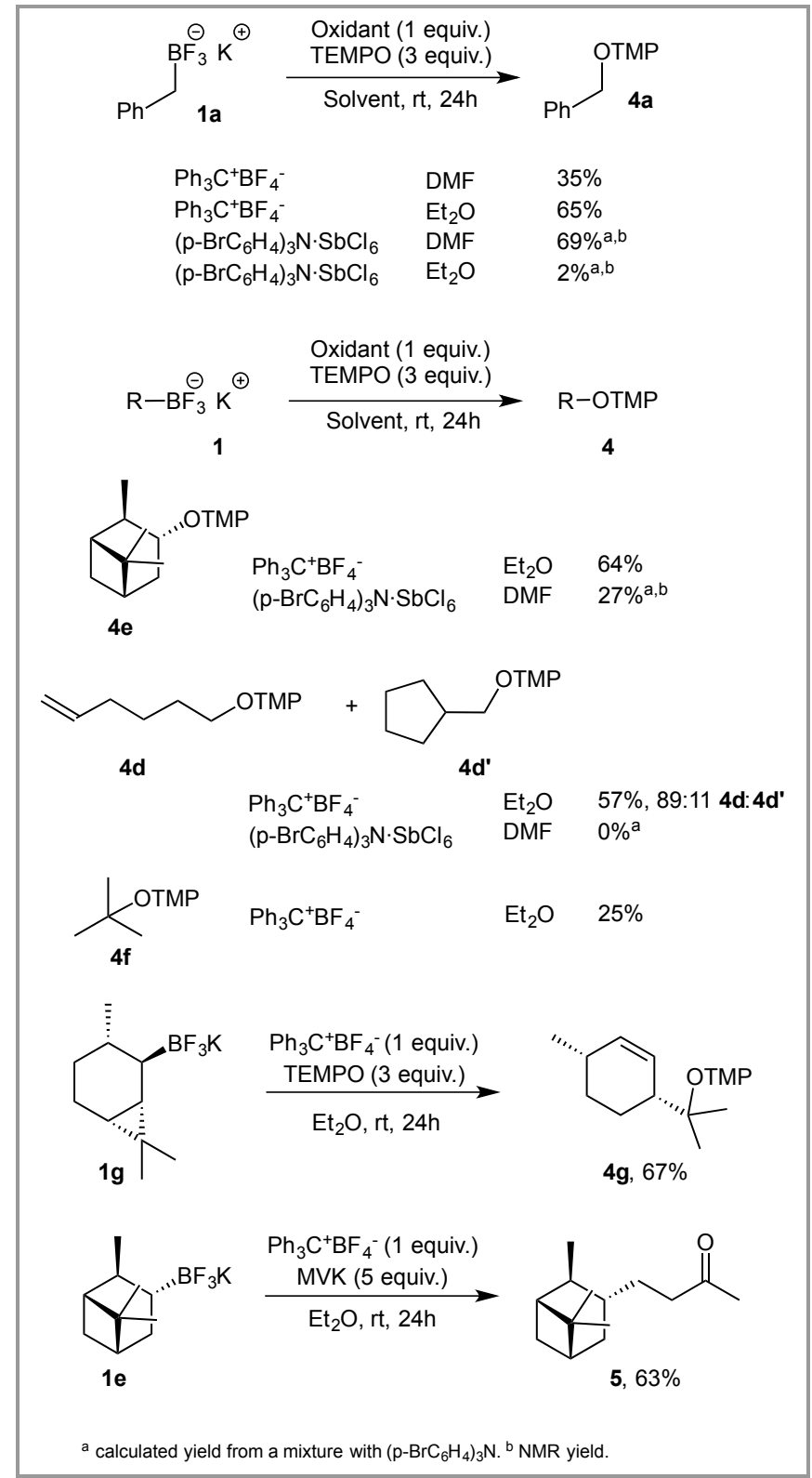

Scheme 2

We also examined the possibility of using Ledwith-Weitz aminium salt (oxidation potential: $1.06 \mathrm{~V}$ vs SCE) ${ }^{10}$ as SET oxidative agent of soft carbanions which to the best of our knowledge has never been accomplished. A strong solvent effect ( $\mathrm{Et}_{2} \mathrm{O}$ vs. DMF) was observed in the oxidation of $\mathbf{1 a}$, respectively $2 \%$ vs. $69 \%$ of 4 a. This led us to pursue our study in DMF with this oxidant. However, even in this solvent, the results proved to be much less satisfying compared to the ones obtained with the tritylium oxidant. Only $27 \%$ yield (4e) with the secondary substrate 1e, and no TEMPO adduct in the primary alkyl series.

Next, we investigated the reactivity of bis-catecholato pentavalent silicates $\mathbf{3}$. These substrates are amenable to large scale synthesis and can be rendered rock stable by complexing the potassium counteranion by the $18-\mathrm{C}-6$ crown ether. ${ }^{3 a}$ Benzyl silicate 3a served as a preliminary probe. It was submitted in $\mathrm{Et}_{2} \mathrm{O}$ and DMF to 1 equiv of tritylium and aminium. In both solvents, tritylium gave poor yields of $\mathbf{4 a}(<20 \%)$. However, the use of the aminium salt was more rewarding (86\% of $\mathbf{4 a}$ in DMF, $16 \%$ in $\mathrm{Et}_{2} \mathrm{O}$ ). ${ }^{11}$ This oxidant proved to be competent in DMF for secondary and primary alkyl substrates giving respectively $44 \%$ of $\mathbf{4 j}$ and $61 \%$ of $\mathbf{4 d , d}$. Tritylium can also be used as a reliable alternative oxidant for the silicates 3 .

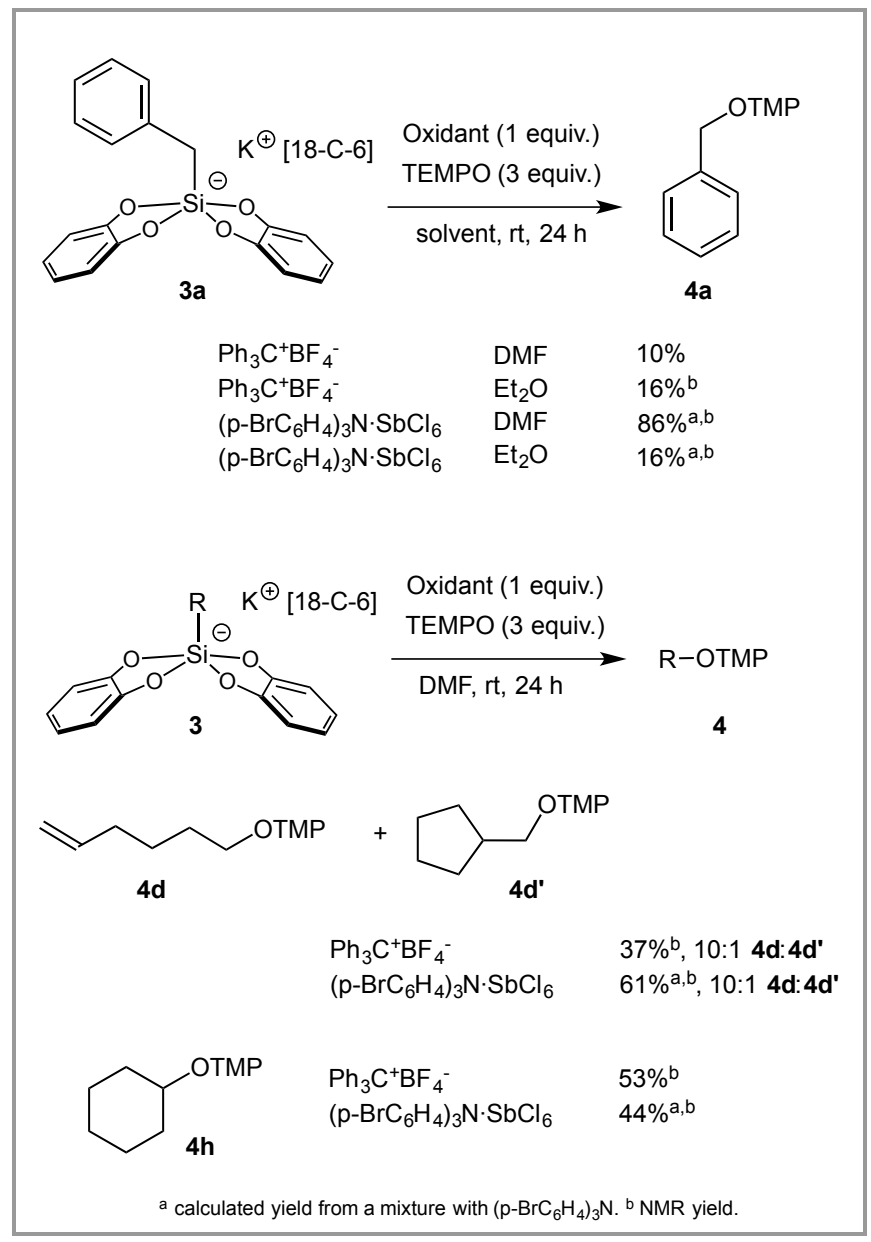

Scheme 3

Because of its mild conditions and high substrate tolerance, visible light photocatalytic oxidation was the obvious next step. ${ }^{12}$ In the case of trifluoroborates, several groups have established the feasibility of this transformation using ruthenium (II) or iridium (III) based photocatalysts. ${ }^{13}$ Of note, the resulting radicals can be engaged in photoredox/nickel dual catalysis. ${ }^{13 g-k}$ While pentafluorosilicates 2 failed in our hands to undergo any oxidation, ${ }^{14}$ we recently showed that biscatecholato silicates constitute advantageous alternatives to the trifluoroborates since they allow upon iridium(III) $\operatorname{Ir}\left[\left(\mathrm{dF}\left(\mathrm{CF}_{3}\right) \mathrm{ppy}\right)_{2}(\mathrm{bpy})\right]\left(\mathrm{PF}_{6}\right)$ photocatalysis the generation of very unstabilized primary radicals, also successfully engaged in photoredox/nickel dual catalysis. ${ }^{3}$

Herein, we wanted to examine the possibility to use organic dyes $^{12,15}$ as possible catalysts for the oxidation of these soft carbanions. Based on their frequent use, the following dyes were considered: Eosin Y, Fluorescein ${ }^{16}$ and Fukuzumi catalyst. ${ }^{17}$ A preliminary screening with benzyltrifluoroborate 1a showed that the Fukuzumi catalyst was by far the best one 


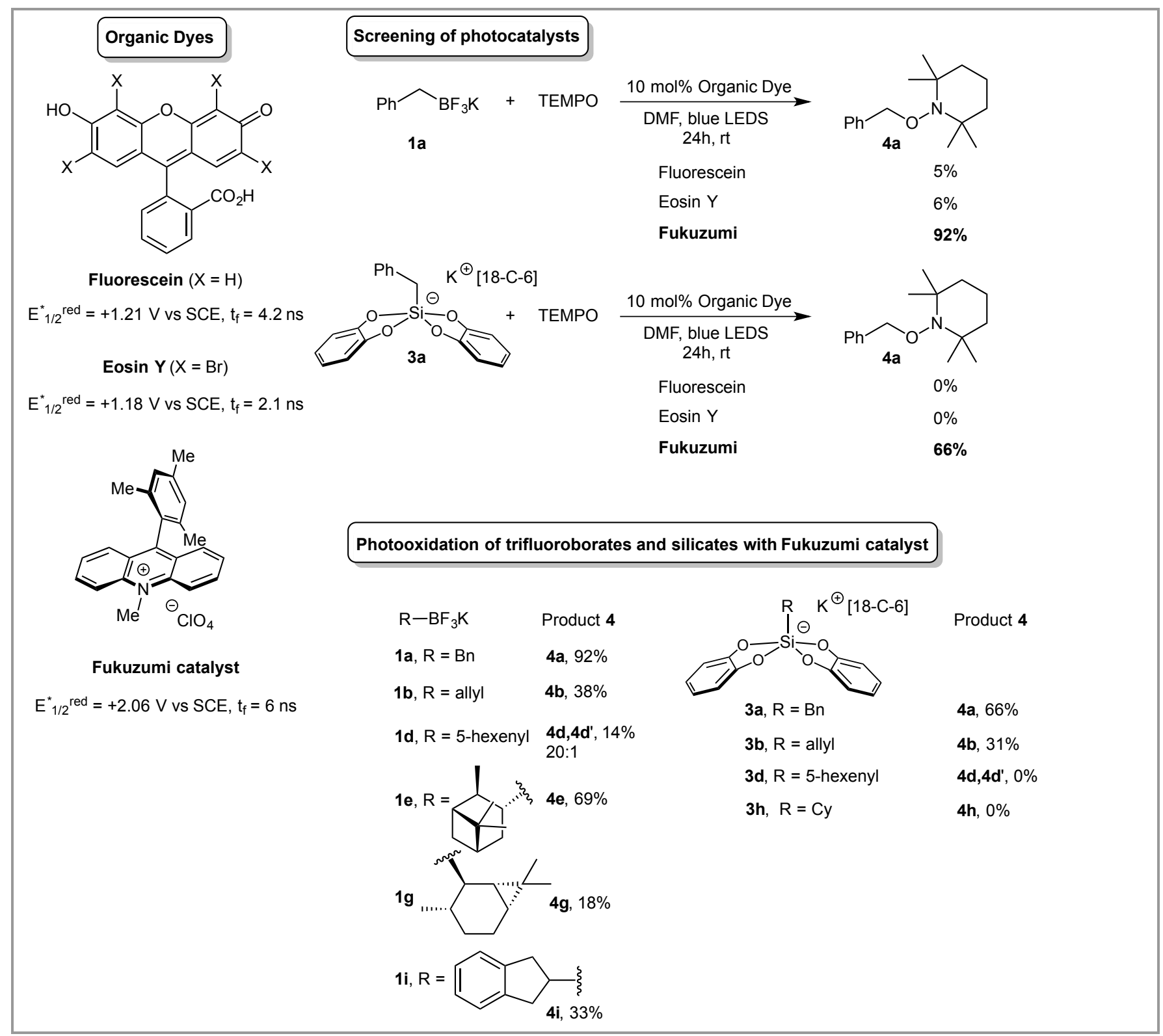

Scheme 4

(Scheme 4). Similar behavior was observed for 3a. Therefore, kept this catalyst for further testing. Both substrate families showed the same trend i.e. the less stabilized is the generated radical, the lower is the yield. Thus, for trifluoroborates, a gradual decrease of yield was observed from benzyl product $\mathbf{4 a}$ to least stabilized primary radical adducts $\mathbf{4 d}, \mathbf{4 d}$ '. One could argue that $\mathbf{1 g}$, a secondary substrate, should have given a better yield. But in that case, the final radical is a tertiary one which may undergo competitive pathways and lead to only $18 \%$ of $\mathbf{4 g}$. In the case of silicates $\mathbf{3}$, only stabilized benzyl and allyl radicals could be generated ( $66 \%$ for $\mathbf{4 a}, 31 \%$ for $\mathbf{4 b}$ ). Interestingly, allyltrifluoroborate $\mathbf{1 b}$ and allylsilicate $\mathbf{3 b}$ provided $\mathbf{4 b}$ in close yields (38\% vs. 31\%). In sharp contrast however, secondary trifluoroborates could give TEMPO adducts $\mathbf{4 e}$ and $\mathbf{4 i}$ contrary to secondary silicate $\mathbf{3 h}$ (no $\mathbf{4 h}$ formed). ${ }^{18}$
A direct correlation of these findings with redox potentials is not obvious. Oxidation potentials for trifluoroborates span from $1.1 \mathrm{~V}$ (benzyl et alkoxymethyl) to $1.83 \mathrm{~V}$ vs SCE (primary and aryl) ${ }^{13 a-b, 12 s}$ while they have been determined to range from 0.61 $\mathrm{V}$ for benzylsilicate $\mathbf{3 a}$ to $0.75 \mathrm{~V}$ vs SCE for $\mathbf{3 d}$. $^{3}$ Some other key factors are at play in these reactions that we will try to uncover. In all the successful oxidations, TEMPO would act as a sacrifial oxidant to regenerate the photocatalyst and sustain the photocatalytic cycle which is consistent with literature data. $3 \mathrm{a}, 13 \mathrm{a}, 19$

In conclusion, this study shows the unprecedented oxidation of trifluoroborates and silicates with a tritylium or an aminium salt as stoichiometric oxidant to generate C-centered radicals. Photocatalytic oxidation could also be achieved with the Fukuzumi acridinium showing a higher reactivity of 
trifluoroborates than silicates in these conditions. Studies are ongoing to improve silicates photooxidation with organic dyes. The effect of the silyl substituents will notably be studied.

\section{Acknowledgment}

We warmly thank CNRS, UPMC, UHA, IUF, MSER (ASF PHD grant to CL), ANR CREDOX, LABEX MiChem (ANR-11-IDEX-0004-02), La Région Martinique (PhD grant to LC), ANR NHCX (11-BS07-008, postdoc grant to VC). COST Action CM1201 is gratefully acknowledged.

\section{Supporting Information}

\section{References and Notes}

(1) a) Dalko, P. I. Tetrahedron 1995, 51, 7579. b) Jahn, U. In Top. Curr. Chem., Radicals in Organic Synthesis, Vol. 3, Heinrich, M.; Gansäuer, A., Eds; Wiley-VCH, Weinheim 2012, 320, 121, 191 and 323. c) Gansäuer, A.; Bluhm, H. Chem. Rev. 2000, 100, 2771.

(2) a) Schuster, G. B. Pure Appl. Chem. 1990, 62, 1565. b) Shundrin, L. A.; Bardin, V. V.; Frohn, H.-J. Z. Anorg. Allg. Chem. 2004, 630, 1253. c) Molander, G. A.; Colombel, V.; Braz, V. A. Org. Lett. 2011, 13, 1852. d) Lockner, J. W.; Dixon, D. D.; Risgaard, R.; Baran, P. S. Org. Lett. 2011, 13, 5628. e) Fujiwara, Y.; Domingo, V.; Seiple, I. B.; Gianatassio, R.; Bel, M. D.; Baran, P. S. J. Am. Chem. Soc. 2011, 133 3292. f) Liwosz, T. W.; Chemler, S. R. Org. Lett. 2013, 15, 3034. g) Neufeldt, S. R.; Seigerman, C. K.; Sanford, M. S. Org. Lett. 2013, 15, 2302. For the oxidation of boronic acids, see: h) Brown, H. C.; Hébert, N. C.; Snyder, C. H. J. Am. Chem. Soc. 1961, 83, 1001. i) Demir, A. S.; Reis, Ö.; Emrullahoglu, M. J. Org. Chem. 2003, 68, 578. j) Dickschat, A.; Studer, A. Org. Lett. 2010, 12, 3972. k) Tobisu, M.; Koh, K.; Furukawa, T.; Chatani N. Angew. Chem. Int. Ed. 2012, 51, 11363.

(3) a) Corcé, V.; Chamoreau, L. M.; Derat, E.; Goddard, J.-P.; Ollivier, C.; Fensterbank, L. Angew. Chem. Int. Ed. 2015, 54, 11414. During the course of our investigations, the following complementary report appeared, see: b) Jouffroy, M.; Primer, D. N.; Molander, G. A. J. Am. Chem. Soc. DOI: 101021/jacs5b10963.

(4) a) Holmes, R. R. Chem. Rev. 1990, 90, 17. b) Chuit, C.; Corriu, R. J. P.; Reye, C.; Young, J. C. Chem. Rev. 1993, 93, 1371.

(5) Sorin, G.; Mallorquin, R. M.; Contie, Y.; Baralle, A.; Malacria, M.; Goddard, J-P.; Fensterbank, L. Angew. Chem. Int. Ed. 2010, 49, 8721.

(6) a) Nishigaichi, Y.; Orimi, T.; Takuwa, A. J. Organomet. Chem. 2009 694, 3837. b) Carzola, C.; Metay, E.; Andrioletti, B.; Lemaire, M. Tetrahedron Lett. 2009, 50, 6855.

(7) For seminal work, see: Yoshida, J.-I.; Tamao, K.; Kakui, T.; Kurita, A.; Murata, M.; Yamada, K.; Kumada, M. Organometallics 1982, 1, 369.

(8) Tritylium is known as a hydride abstractor, for a recent application, see: a) Xie, Z.; Liu, L.; Chen, W.; Zheng, H.; Xu, Q.; H. Yuan, H.; Lou, H Angew. Chem. Int. Ed. 2014, 53, 3904 and references therein. It has been used as a sacrificial electron acceptor in photoredox catalysis, see: b) Daniel, M.; Fensterbank, L.; Goddard, J.-P.; Ollivier, C. Org. Chem. Front. 2014, 1, 551.

(9) To a schlenk flask was added potassium 5-hexenyl-1trifluoroborate 1d or potassium [18-Crown-6] bis(catecholato)-5hexenyl-1-silicate ( $0.3 \mathrm{mmol}, 1$ equiv.) 3d, the oxidizing agent (0.3 mmol, 1 equiv.) and TEMPO (0.9 mmol, $141 \mathrm{mg}, 3$ equiv.). The schlenk flask was sealed with a rubber septum, and evacuated / purged with vacuum / argon three times. Degassed diethyl ether -or DMF- (3 mL) was introduced followed by two freeze-pump-thaw cycles. The reaction mixture was stirred at room temperature for $24 \mathrm{~h}$ under an argon atmosphere. The reaction mixture was diluted with diethyl ether $(50 \mathrm{~mL})$, washed with water -or $\mathrm{NaHCO}_{3}$ - (2 times), brine (2 times), dried over $\mathrm{MgSO}_{4}$ and evaporated under reduced pressure. The reaction residue was purified by flash column chromatography on silica gel to afford a unseperable mixture of $\mathbf{4 d}$ and $\mathbf{4 d}$ ' in a 9:1 to 10:1 ratio and an overall yield (37-61\%) depending on the oxidizing agent. (4d) : ${ }^{1} \mathrm{H} \mathrm{NMR}\left(\mathrm{CDCl}_{3}, 400 \mathrm{MHz}\right): 5.82(\mathrm{~m}, 1 \mathrm{H}), 5.01(\mathrm{~m}, 1$ $\mathrm{H}), 4.94(\mathrm{~m}, 1 \mathrm{H}), 3.73(\mathrm{t}, J=6.1 \mathrm{~Hz}, 2 \mathrm{H}), 2.07(\mathrm{q}, J=7.2 \mathrm{~Hz}, 2 \mathrm{H})$, 1.55-1.20 (m, 10H), $1.14(\mathrm{~s}, 6 \mathrm{H}), 1.09(\mathrm{~s}, 6 \mathrm{H}) \mathrm{ppm} .{ }^{13} \mathrm{C}$ NMR $\left(\mathrm{CDCl}_{3}, 100 \mathrm{MHz}\right):$ 139.1, 114.5, 80.8, 59.9, 59.8, 39.7, 34.0, 33.2, 28.4, 25.9, 20.3, $17.3 \mathrm{ppm}$. (4d') : ${ }^{1} \mathrm{H}$ NMR $\left(\mathrm{CDCl}_{3}, 400 \mathrm{MHz}\right)$ : Characteristic signal at $3.64 \mathrm{ppm}\left(-\mathrm{CH}_{2}-\mathrm{O}\right) \cdot{ }^{13} \mathrm{C}$ NMR $\left(\mathrm{CDCl}_{3}, 100\right.$ $\mathrm{MHz})$ : Characteristic signal at $76.7 \mathrm{ppm}\left(-\mathrm{CH}_{2}-\mathrm{O}\right)$.

(10) a) Herath, A. C.; Becker, J. Y. J. Electroanal. Chem. 2008, 619-20, 98. b) Brinkhaus, K. H. G.; Steckhan, E.; Schmidt, W. Acta Chem. Scand. 1983, B37, 499. c) Wend, R.; Steckhan, E. Electrochim. Acta. 1983, 42, 2027. For a recent use, see: d) Drew, S. L.; Lawrence, A. L.; Sherburn, M. S. Angew. Chem. Int. Ed. 2013, 52, 4221.

(11) In comparison, oxidation with 1 equiv of $\mathrm{Cu}(\mathrm{OAc})_{2}$ gave $45 \%$ yield of $\mathbf{4 a}$ and with 1 equiv of DMP, $26 \%$ of $\mathbf{4 a}$.

(12) For selected reviews on visible-light photoredox catalysis, see: a) Zeitler, K. Angew. Chem. Int. Ed. 2009, 48, 9785. b) Yoon, T. P.; Ischay, M. A.; Du, J. Nature Chem. 2010, 2, 527. c) Teplý, F. Collect. Czech. Chem. Commun. 2011, 76, 859. d) Narayanaman, J. M. R.; Stephenson, C. R. J. Chem. Soc. Rev. 2011, 40, 102. e) Tucker, J. W.; Stephenson, C. R. J. J. Org. Chem. 2012, 77, 1617. f) Xuan, J.; Xiao, W.-J. Angew. Chem. Int. Ed. 2012, 51, 6828. g) Ischay, M. A.; Yoon, T. P. Eur. J. Org. Chem. 2012, 3359. h) Maity, S.; Zheng, N. Synlett 2012, 23, 1851. i) Shi, L.; Xia, W. Chem. Soc. Rev. 2012, 41, 7687; j) Xi, Y.; Yi, H.; Lei, A. Org. Biomol. Chem. 2013, 11, 2387. k) Prier, C. K.; Rankic, D. A.; MacMillan, D. W. C. Chem. Rev. 2013, 113, 5322. l) Hari, D. P.; König, B. Angew. Chem. Int. Ed. 2013, 52, 4734. m) Reckenthäler, M.; Griesbeck, A. G. Adv. Synth. Catal. 2013, 355, 2727. n) Koike, T.; Akita, M. Synlett 2013, 24, 2492. o) Xuan, J.; Lu, L.-Q.; Chen, J.-R.; Xiao, W.-J. Eur. J. Org. Chem. 2013, 6755. p) Zou, Y.-Q.; Chen, J.-R.; Xiao, W.-J. Angew. Chem. Int. Ed. 2013, 52, 11701. q) Hu, J.; Wang, J.; Nguyen, T. H.; Zheng, N. Beilstein J. Org. Chem. 2013, 9, 1977. r) Xie, J.; Jin, H.; Xu, P.; Zhu, C. Tetrahedron Lett. 2014, 55, 36. s) Koike, T.; Akita, M. Inorg. Chem. Front. 2014, 1, 562. t) Hopkinson, M. N.; Sahoo, B.; Li, J.-L.; Glorius, F. Chem. Eur. J. 2014, 20, 3874. u) Schultz, D. M.; Yoon, T. P. Science 2014, 343, 985. For recent books, see: v) Chemical Photocatalysis, König, B., Eds., DeGruyter, Berlin, 2013. w) Photochemically generated intermediates in Synthesis, Albini, A.; Fagnoni, M., Eds., John Wiley \& Sons, Hoboken, 2013.

(13) a) Yasu, Y.; Koike, T.; Akita, M. Adv. Synth. Catal. 2012, 354, 3414. b) Miyazawa, K.; Yasu, Y.; Koike, T.; Akita, M. Chem. Commun. 2013, 49, 7249. c) Koike, T.; Akita, M. Synlett 2013, 24, 2492. d) Miyazawa, K.; Koike, T.; Akita, M. Adv. Synth. Catal. 2014, 356, 2749. e) Li, Y.; Miyazawa, K.; Koike, T.; Akita, M. Org. Chem. Front. 2015, 2, 319. f) Huang, H.; Zhang, G.; Gong, L.; Zhang, S.; Chen, Y. J. Am. Chem. Soc. 2014, 136, 2280. g) Tellis, J. C.; Primer, D. N.; Molander, G. A. Science 2014, 345, 433. h) Primer, D. N.; Karakaya, I.; Tellis, J. C.; Molander, G. A. J. Am. Chem. Soc. 2015, 137, 2195. i) Gutierrez, O.; Tellis, J. C.; Primer, D. N.; Molander, G. A.; Kozlowski, M. C. J. Am. Chem. Soc. 2015, 137, 4896. j) Karakaya, I.; Primer, D. N.; Molander, G. A. Org. Lett. 2015, 17, 3294. k) Yamashita, Y.; Tellis, J. C.; Molander, G. A. Proc. Natl. Acad. Sci. U. S. A. 2015, 112, 12026 l) Huang, H.; Jia, K.; Chen, Y. Angew. Chem. Int. Ed. 2015, 54, 1881.

(14) Allyl-, cyclopentyl-, $t$ - $\mathrm{Bu}-\mathrm{SiF}_{5} \mathrm{~K}_{2}$ did not give any TEMPO adduct 4 in the following conditions $(2 \mathrm{~mol} \%$ $\operatorname{Ir}\left[\left(\mathrm{dF}\left(\mathrm{CF}_{3}\right) \text { ppy }\right)_{2}(\mathrm{bpy})\right]\left(\mathrm{PF}_{6}\right)$, acetone or DMF, TEMPO (2.5 equiv), blue LED).

(15) a) Fukuzumi, S.; Ohkubo, K. Org. Biomol. Chem. 2014, 12, 6059. b) Nicewicz, D. A.; Nguyen, T. M. ACS Catal. 2014, 4, 355. c) Ravelli, D.; Fagnoni, M. ChemCatChem 2012, 4, 169. For a recent use, see: d) Griffin, J. D.; Zeller, M. A.; Nicewicz, D. A. J. Am. Chem. Soc. 2015, $137,11340$.

(16) Zhang, X.-F.; Zhang, I.; Liu, L. Photochem. Photobiol. 2010, 86, 492.

(17) a) Fukuzumi, S.; Kotani, H.; Okhubo, K.; Ogo, S.; Tkachenko, N. V.; Lemmetyinen, H. J. Am. Chem. Soc. 2004, 126, 1600. b) Benniston, 
A. C.; Harriman, A.; Li, P.; Rostron, J. P.; van Ramesdonk, H. J.; Groeneveld, M. M.; Zhang, H.; Verhoeven, J. W. J. Am. Chem. Soc. 2005, 127, 16054.

(18) To a schlenk flask were added the organotrifluoroborate $\mathbf{1}$ or organosilicate 3 (0.3 mmol, 1 equiv.), 9-mesityl-10methylacridinium perchlorate as photocatalyst $(0.03 \mathrm{mmol}, 10$ mol\%) and TEMPO (0.66 mmol, 2.2 equiv.). The schlenk flask was sealed with a rubber septum, and evacuated-purged with vacuum-argon three times. Degassed DMF (3 mL) was introduced followed by two freeze-pump-thaw cycles. The reaction mixture was stirred at room temperature for $24 \mathrm{~h}$ under an argon atmosphere. The reaction mixture was diluted with diethyl ether $(50 \mathrm{~mL})$, washed with saturated $\mathrm{NaHCO}_{3}$ (2 times), brine (2 times), dried over $\mathrm{MgSO}_{4}$ and evaporated under reduced pressure. The reaction residue was purified by flash column chromatography on silica gel.

(19) The generated TEMPO N-oxide anion could be silylated or borylated. The resulting anionic products would be eliminated during the aqueous work-up. We thank one of the referees for this suggestion. 